\title{
New locations of rare lichen species in the Krasnoyarsk region
}

\author{
Natalya Eromasova ${ }^{1, * *}$, and Olga Zyryanova ${ }^{1}$ \\ ${ }^{1}$ Khakas state University n. a. N. F. Katanov, 655000, Abakan, Russia
}

\begin{abstract}
As a result of lichenological studies of the Salbinka River valley, new locations of lichen species listed in the Red Data Books of the Russian Federation and the Krasnoyarsk Territory have been identified. New habitats of Usnea longissima Ach., Lobaria isidiophora Yoshim., Lobaria scrobiculata (Scop.) P. Gaertn. and Lobaria pulmonaria (L.) Hoffm. have been revealed. Their brief characteristics in the studied habitats are given and the state of thalli is described.
\end{abstract}

\section{Introduction}

6 years have passed since the last edition of the Red Book of the Krasnoyarsk Territory was published. Since that time, data on the distribution of lichen species under protection have been added, which will undoubtedly be taken into account in the development of the next edition. Recent lichenology studies focused directly on rare species are concentrated in the Western Sayan [1-3]. It is worth noting that the majority of lichen species, for which the locations in the Ermakovsky area are marked, are confined to taiga forests [4]. This article includes data on the new locations of rare species included in the Red Data Books of the Russian Federation [5] and the Krasnoyarsk Territory [4], discovered during lichenogical studies [6-7] in the Salbinka River valley (Ermakovskiy district, Krasnoyarsk Territory).

\section{Materials and Methods}

The studies were conducted in the spring-autumn period from 2015 to 2017 using the route method of floristic studies [8]. The territory of our study is located in the subtaiga subzone, where the dominants in the tree layer are Betula pendula Roth. and Pinus sylvestris L., in some places with an admixture of Populus tremula L. The species of lichens mentioned above, according to the known literary data, were not marked in such phytocenoses. The nomenclature of lichens is listed in accordance with the "List of lichen flora of Russia" [8], as well as the sites of the Consortium of North American Lichen Herbaria and Index Fungorum.

In determining the species, a binocular microscope MBS-10, microscope Micromed-1, reagents: $10 \% \mathrm{KOH}$ solution, solution $\mathrm{I}(\mathrm{J}+\mathrm{KJ})$ and paraphenylenediamine $(\mathrm{C} 6 \mathrm{H} 4(\mathrm{NH} 2)$

\footnotetext{
* Corresponding author: eromasova@inbox.ru
} 
2) were used. The collections are stored in the Scientific Herbarium of the KSU. N.F. Katanova (HGU).

\section{Results and discussion}

In the study area, 4 species of lichens listed in the Red Data Books of the Russian Federation and the Krasnoyarsk Territory - Usnea longissima Ach., Lobaria isidiophora Yoshim., Lobaria scrobiculata (Scop.) P. Gaertn., Lobaria pulmonaria (L.) Hoffm. were found.

All of them, except Lobaria pulmonaria (L.) Hoffm., were found in new habitats, not typical for their usual location.

Usnea longissima Ach. It grows in humid areas of the region, mostly in dark coniferous taiga and mountain taiga old-growth frontier forests. It settles on the branches of coniferous trees. Common in the Sayans [4]. In the investigated territory, this species was found in a birch forest, on Betula pendula Roth., although it is not typical for it, as it is found only in coniferous trees in taiga forest conditions. Thallus, due to the natural and climatic conditions of the study area, differs from taiga specimens in smaller sizes, fibrils are also shorter.

Lobaria isidiophora Yoshim. This species is confined to dark coniferous mountain taiga old-growth forests, found on the Kulumys ridge and in the vicinity of the village of Tanzibey [4]. In the study area the species is marked in birch-pine and birch forests. It occurs mainly on old, often already dead trunks of species of the genus Salix L. Lichen is distributed unevenly in the territory. The largest concentrations are observed in places with high humidity: near the Salbinka River, streams and wetlands. Young thalli are rare, most of the detected specimens are old lichens with damage of varying degrees.

Lobaria scrobiculata (Scop.) P. Gaertn. It is confined to dark coniferous mountain-taiga forests of the Sayans, less often to subtaiga. In the Ermakovsky region it is noted for mountain-forest territories of the Sayans [4]. On the study area is found in birch forests, rarely. Most often these are small solitary thalli, which are adjacent to specimens of other species of Lobaria. Damage to the thallus was not noticed. As a forrophyte, Betula pendula Roth., Was also found on a moss covered boulder. Damage to the thalli was not noticed. As a forrophite, it uses Betula pendula Roth., also found on a moss covered boulder.

Considering the above species, Lobaria pulmonaria (L.) Hoffm should also be noted, with no new locations for it. It is distributed throughout the south of the Krasnoyarsk Territory to the latitude of Krasnoyarsk: in subtaiga, taiga and dark coniferous mountain taiga, Minusinsk depression [4]. Among the protected species, this is the most abundant and evenly distributed species in the study area. It prefers Betula pendula Roth. as forophyte, it can also be found on species of the genus Salix L., was singularly found on Populus tremula L. It was marked that this lichen grows mainly on trees, the trunk of which has a strong slope relative to the soil level. We believe that this regularity is associated with a longer retention of moisture by the trunks that are closer to the horizontal position. In general, individuals grow in small groups, rarely singly or form a continuous cover from the base of the trunk to $1.5 \mathrm{~m}$ in height on old birches. Completely undamaged thalli are rare, most are in a collapsing state, and this applies not only to old thalli, but also to very young ones.

\section{Conclusions}

Thus, we investigated the new locations of four protected species: Usnea longissima Ach. and Lobaria scrobiculata (Scop.) P. Gaertn. are found in birch forests; Lobaria isidiophora 
Yoshim. - in birch and birch-pine forests; Lobaria pulmonaria (L.) Hoffm. on the investigated territory is marked in birch and birch-pine forests. Most of the thalli of Lobaria isidiophora Yoshim. and Lobaria pulmonaria (L.) Hoffm. are in a collapsing state. To this state of thalli of the species examined, perhaps, the increasing anthropogenic factor led, in the form of a close location of the federal highway P257 "Yenisei" and populated areas. Also in the study area and nearby logging is conducted.

We are grateful to Ph.D in Biology Kharitonenkov Maxim for assistance in preparing the publication.

\section{References}

1. T.N.Otnyukova, N.V. Stepanov, Modern Mycology in Russia 2, 532-533 (2008)

2. N.V. Stepanov, The Bulletin of KrasGAU 4, 47-52 (2010)

3. N.V. Stepanov, The Bulletin of KrasGAU 3, 163-170 (2017)

4. Red Book of the Krasnoyarsk territory. The Rare and Endangered Species of Wild Plants and Funguses (Krasnoyarsk, 2012)

5. Red Book of the Russian Federation (Plants and Funguses). (Moscow, 2008)

6. N.I. Eromasova, Ecology of the Southern Siberia and adjacent territories 20, 21-22 (2016)

7. N.I. Eromasova, Juvenis scientia. 4, 12-14 (2017)

8. Lichen flora of Russia: Biology, ecology, diversity, distribution and methods '3 study of lichens. (Moscow; Saint-Petersburg: Association of scientific publications KMK, 2014) 